Original Article

\title{
Ameliorative effects of morel mushroom (Morchella esculenta) against Cadmium-induced reproductive toxicity in adult male rats
}

\author{
Efeitos benéficos do cogumelo morel (Morchella esculenta) contra a toxicidade \\ reprodutiva induzida por cádmio em ratos machos adultos
}

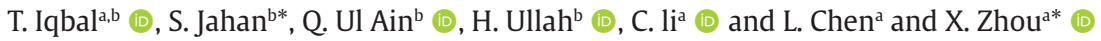 \\ ajilin University, College of Animal Science and Veterinary Medicine, Lab of Animal Genetics, Breeding and Reproduction, Changchun, China \\ 'Quaid-i-Azam University, Department of Animal Sciences, Reproductive Physiology Lab, Islamabad, Pakistan
}

\begin{abstract}
Cadmium (Cd) is one of the major toxicants, which affects human health through occupational and environmental exposure. In the current study, we evaluated the protective effects of morel mushrooms against Cd-induced reproductive damages in rats. For this purpose, 30 male rats were divided into 6 groups ( $n=5 / g r o u p)$, the first group served as the control group, second group was treated with an intraperitoneal (i.p) injection of $1 \mathrm{mg} / \mathrm{kg} / \mathrm{day}$ of Cd. Third and fourth groups were co-treated with $1 \mathrm{mg} / \mathrm{kg} /$ day of Cd (i.p) and 10 and $20 \mathrm{mg} / \mathrm{kg} / \mathrm{day}$ of morel mushroom extract (orally) respectively. The final 2 groups received oral gavage of 10 and $20 \mathrm{mg} / \mathrm{kg} / \mathrm{day}$ of morel mushroom extract alone. After treatment for 17 days, the animals were euthanized, and testes and epididymis were dissected out. One testis and epididymis of each animal were processed for histology, while the other testis and epididymis were used for daily sperm production (DSP) and comet assay. Our results showed that Cd and morel mushrooms have no effect on animal weight, but Cd significantly decreases the DSP count and damages the heritable DNA which is reversed in co-treatment groups. Similarly, the histopathological results of testes and epididymis show that morel mushrooms control the damage to these tissues. Whereas the morel mushroom extract alone could enhance the production of testosterone. These results conclude that morel mushrooms not only control the damage done by $\mathrm{Cd}$, but it could also be used as a protection mechanism for heritable DNA damage.
\end{abstract}

Keywords: cadmium toxicity, Morchella esculenta, herbal medicine, DNA damage, spermatogenesis.

\begin{abstract}
Resumo
O cádmio (Cd) é um dos principais tóxicos, que afeta a saúde humana por meio da exposição ocupacional e ambiental. No presente estudo, avaliamos os efeitos protetores dos cogumelos morel contra os danos reprodutivos induzidos pelo Cd em ratos. Para tanto, 30 ratos machos foram divididos em 6 grupos ( $n=5$ / grupo); o primeiro grupo serviu de controle, o segundo grupo foi tratado com injeção intraperitoneal (i.p) de $1 \mathrm{mg} / \mathrm{kg} / \mathrm{dia}$ de Cd. O terceiro e o quarto grupos foram cotratados com $1 \mathrm{mg} / \mathrm{kg}$ / dia de Cd (i.p) e 10 e $20 \mathrm{mg} / \mathrm{kg} /$ dia de extrato de cogumelo morel (por via oral), respectivamente. Os dois grupos finais receberam gavagem oral de 10 e $20 \mathrm{mg} / \mathrm{kg}$ / dia de extrato de cogumelo morel sozinho. Após o tratamento por 17 dias, os animais foram sacrificados e os testículos e o epidídimo foram dissecados. Um testículo e epidídimo de cada animal foram processados para histologia, enquanto o outro testículo e epidídimo foram usados para produção diária de esperma (DSP) e ensaio cometa. Nossos resultados mostraram que os cogumelos Cd e morel não têm efeito sobre o peso do animal, mas o Cd diminui significativamente a contagem de DSP e danifica o DNA hereditário, que é revertido em grupos de cotratamento. Da mesma forma, os resultados histopatológicos dos testículos e do epidídimo mostram que os cogumelos morel controlam os danos a esses tecidos. Considerando que o extrato de cogumelo morel sozinho pode aumentar a produção de testosterona. Esses resultados concluem que os cogumelos morel não apenas controlam os danos causados pelo Cd, mas também podem ser usados como um mecanismo de proteção para danos hereditários ao DNA.
\end{abstract}

Palavras-chave: toxicidade de cádmio, Morchella esculenta, fitoterapia, dano ao DNA, espermatogênese.

*e-mail: xzhou65@vip.sina.com; sjahan@qau.edu.pk

Received: May 11, 2021 - Accepted: June 30, 2021 


\section{Introduction}

Heavy metal pollution is a challenging and ill-posed problem affecting the cellular physiology of living organisms (Cheng et al., 2019; Islam et al., 2018; Qing et al., 2015; Zhuang et al., 2009). The modern world depends on industrialization to meet the demand for different daily used products, which results in the production of different toxicants as by-products. Mostly these by-product toxicants are disposed to environment. Among theses One important by-product toxicant is Cadmium (Cd), featured by its solubility in water, transferability, persistence and durability, universality, and severe toxicity (Li et al., 2015). Because of these properties, $\mathrm{Cd}$ is reported as the sixth most dangerous chemical for living things by the Agency of Toxic substances and Disease Registry (ATSDR) (Li et al., 2018; Ramelli et al., 2009; Zhang et al., 2017). Despite these hazardous features of $\mathrm{Cd}$ and warning of ATSDR, the world health organization (WHO) reported that the quantity of $\mathrm{Cd}$ is increasing with human activities and accumulate in the air, soil, and water (WHO, 1960; Krzyzanowski and Cohen, 2008; Ramelli et al., 2009; Trejo et al., 2016) resulting in its adsorption by plants, which is diet source for human and animals (Rafati Rahimzadeh et al., 2017; Faroon et al., 2012; Järup and Åkesson, 2009; Ramelli et al., 2009). With respect to food intake, in plant food sources $\mathrm{Cd}$ is found in cereals (wheat and rice), root vegetables (potato, celeriac, carrot), and green leafy vegetables, while in animals it is found in cephalopods, crabs, molluscs, crustaceans, and offal products of old animals. It is reported that food from plant sources has a higher concentration of Cd than dairy and poultry products (Järup and Åkesson, 2009).

Recent studies have reported diverse toxic effects of $\mathrm{Cd}$, including teratogenicity, oncogenicity, renal dysfunction, endocrine disruption, and reproductive toxicity (Bernard, 2008; Zhang et al., 2017). According to some epidemiological studies, $\mathrm{Cd}$ and lead $(\mathrm{Pb})$ have an equivocal effect on hormones concentration, sperm parameters, and male infertility (Benoff et al., 2000). In addition to environmental toxicants, climatic seasons and geographical locations greatly affect reproductive physiology (Becker and Berhane, 1997; Fisch and Goluboff, 1996; Paulsen et al., 1996; Šrám et al., 1996). But enough data is available which demonstrate that high concentration of heavy metals like $\mathrm{Cd}$ in the environment are associated with low semen quality (Danielsson et al., 1984; Oldereid et al., 1993; Ragan and Mast, 1990). The exact mechanism of Cd toxicity is not understood completely till now, but in the past few decades, different studies have reported major cellular toxicities including oxidative stress (Casalino et al., 2002; Hussain et al., 1987; Shukla et al., 1987), variation in thiol proteins (Chan and Cherian, 1992; Li et al., 1993), inhibition of mitochondrial activity (Müller, 1986), variation in membrane structure and function (Müller, 1986; Shukla et al., 1987), damage to DNA structure (Coogan et al., 1992), expression of stress gene (Goering et al., 1993; Wang and Templeton, 1998) and variation in some enzymatic activities (Casalino et al., 2002, 2000, 1997; Jay et al., 1991; Manca et al., 1991; Wätjen et al., 2001)
For centuries Morchella Esculenta (ME) along with other species of Morchella has been used in Traditional Chinese Medicine (TCM) because of its active pharmacological constituents (Baati et al., 2011; Duncan et al., 2002; Halliwell, 2012, 2011; Heleno et al., 2013; Meng et al., 2010; Raman, 2018). It is also used as medicine in Japan, Malaysia, India, and Pakistan for its aphrodisiac properties (Gewali, 2009; Raman, 2018; Sud and Sud, 2017). It is reported that the fruiting body of ME contains profound antitumor, anti-inflammatory, and antioxidant activity (Elmastas et al., 2006; Nitha et al., 2010; Nitha and Janardhanan, 2008). To the best of our knowledge, no scientific data regarding its role in reproductive physiology is known.

Based on damages caused by $\mathrm{Cd}$, and the presence of bioactive elements in ME, which could be used in controlling the oxidative in living organisms, the current study is designed to check the effects of Cadmium Chloride $\left(\mathrm{CdCl}_{2}\right)$ administration on reproductive parameters of male rats and whether ME can reverse these effects.

\section{Materials and Methods}

\subsection{Animals}

Thirty adult male Sprague Dawley (SD) rats, having an average weight of $260 \pm 45$ grams, were obtained from animal house of College of Animal Sciences and Veterinary Medicine Jilin University Changchun, and were kept in stainless steel cages according to standard guidelines at controlled temperature $\left(24 \pm 2^{\circ} \mathrm{C}\right)$ and humidity (50-60\%) for one week to acclimatize to lab environment. All the animals were kept at $12 \mathrm{~h} / 12 \mathrm{~h}$ dark/light cycle and were fed with standard feed and had free access to water ad libitum. The whole experiment was approved by the ethical committee of Jilin University Changchun China (Permit Number SY201909012)

\subsection{Chemicals}

Cadmium chloride $\left(\mathrm{CdCl}_{2}\right)$ was purchased from $\mathrm{BDH}$ Chemicals Ltd (pool, England)

\subsection{Collection of $M E$ and preparation of its extract}

Morel Mushrooms (Marchella esculenta) (wild) was obtained from different fields of District Swat Pakistan. It was verified as Morel Mushrooms at the department of Plant sciences Quaid-i-Azam University Islamabad. After verification, the mushrooms were dried under shade and stored in humid free environment.

Ten days before the animal trials started the ME was weighted and mixed with ethanol. The ratio of dried ME and ethanol was roughly 1:3 in bottle. This mixture was on magnetic stirrer for one week.After one week this mixture was filtered using filter paper . The solvent was evaporated, and the remaining extract was weighed and used for further study.

\subsection{Experimental design}

Adult male rats were divided into six groups ( $n=5 /$ group). The first group served as Control group and received 
intraperitoneal (i.p) injection of saline, three groups were treated with an i.p. injection of $1 \mathrm{mg} / \mathrm{kg} /$ day of Cd using $\mathrm{CdCl}_{2}$ solution. Among these 3 groups, 2 groups were co-treated with oral gavage of ME extract (one group was co-treated with $10 \mathrm{mg} / \mathrm{kg} /$ day and the other with $20 \mathrm{mg} / \mathrm{kg} /$ day of ME extract along with Cd). The remaining 2 groups received 10 and $20 \mathrm{mg} / \mathrm{kg}$ of ME extract alone respectively using an oral gavage (Figure 1 ). The exposure of Cd was for 17 days according to ATSDR, Cilenk, and our previous work (Çilenk et al., 2016; Iqbal et al., 2021; Ramelli et al., 2009). On day 18 (roughly 24 hours after last dose administration) the animals were anesthetized and euthanized according to guidelines of Jilin University. Blood plasma was collected for hormonal analysis, while reproductive organs (Testes and Epididymis) were dissected out and processed for tissue and sperm analysis. One of the testis and epididymis of each animal were fixed in $10 \%$ Formaldehyde for histological analysis, while the others were stored at $-70^{\circ} \mathrm{C}$ until further analysis.

Before storing or processing the organs, the volume of testes was measured in measuring cylinder using saline $\left(37^{\circ} \mathrm{C}\right)$ as measuring liquid.

\subsection{Daily sperm production (DSP)}

The testes stored at $-70^{\circ} \mathrm{C}$ were defrosted and used to calculate DSP according to Robb et al.(Robb et al., 1978) with some modifications. Briefly, testes were weighted, tunica albuginea were removed and $90 \mathrm{mg}$ of tissue was homogenized in $2 \mathrm{ml}$ of saline and diluted according to Jahan et al.(Jahan et al., 2016), then 5.5 $\mu$ l of the sample was taken on Neubauer chamber (haemoctmeter), covered with a small coverslip, and late sperm cells were counted under a microscope at 40X magnification.. The DSP was counted using Formula 1

Formula for DSP

$$
Y=\left(\frac{x}{16}\right) \times 100 \times 5 \times 5.5 \times 1000
$$

Where $\mathrm{Y}$ is the total number of spermatids, $\mathrm{x}$ is the number of spermatids counted on hemocytometer. 16 is the total number of squares observed, 100 is the total number of squares, 5 is dilution made, $5.5 \mu \mathrm{l}$ was loaded on the haemocytometer, while 1000 is to convert $\mu$ into $\mathrm{ml}$.

\subsection{Histology}

One testis and epididymis of each animal were fixed in $10 \%$ formaldehyde and dehydrated using different concentrations of ethanol before embedding in paraffin wax. Then 5-7 $\mu \mathrm{m}$ thick sections were cut from the prepared paraffin blocks using a microtome. Sections were affixed on glass slides, deparaffinized, and stained with hematoxylin and eosin (H\&E) stains. These slides were examined using microscope equipped with the micro-photographic system. Different parameters (diameter of seminiferous tubules, interstitial space, diameter of tubular lumen, tunica albuginea, and height of the epithelium) of seminiferous tubules were measured in the slides using image J software.

\subsection{Quantitative determination of Testosterone concentration}

Testosterone concentration in blood plasma was determined using Enzyme Linked Immuno Sorbant Assay (ELISA) kit. The ELISA kit was purchased from Amgenix, Burlingame, CA, USA. All samples were quantified in duplicate in a single assay.
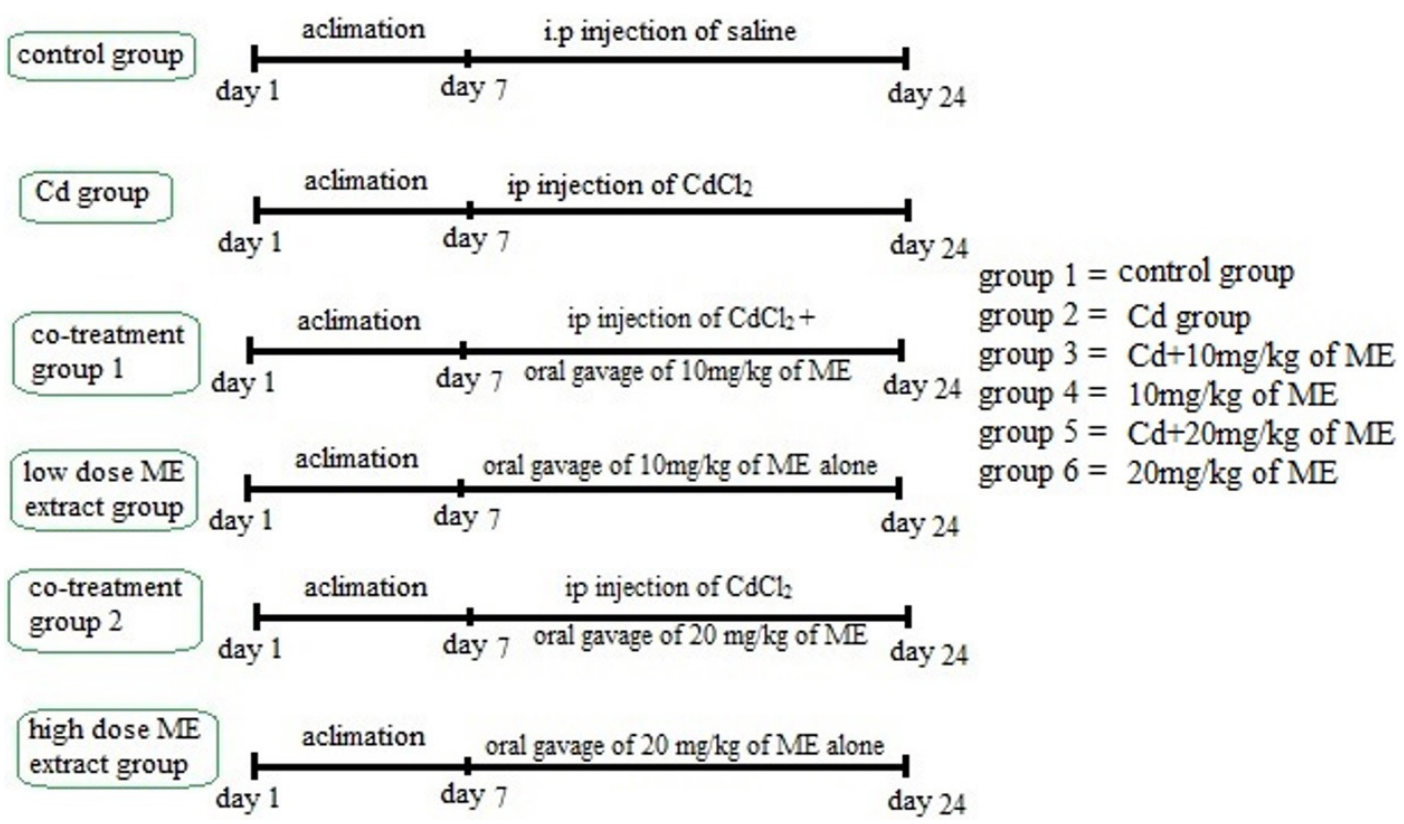

Figure 1. experimental design showing that the control group is treated with ip dosage of saline, 3 groups are treated with ip dosage of $\mathrm{Cd}$, in which 2 received oral dosage of ME, and final 2 groups received oral gavage of ME alone (ME= Morchella esculenta). 


\subsection{Comet assay (single-cell gel electrophoresis (SCGE))}

The DNA damage in sperm cells was determined using comet assay with some modifications (Ahmad et al., 2007). Briefly $100 \mu \mathrm{l}$ of $1 \%$ regular melting point agarose was placed on glass slides and allowed to solidify. After that $20 \mu$ of homogenate of cauda epididymis and $65 \mu \mathrm{l}$ of low melting point- agarose were mixed and spread on the agarose-coated slides. After solidification, slides were submerged in lysing solution (100 mM EDTA Na2, 10mM Tris, $2.5 \mathrm{M} \mathrm{NaCl}, \mathrm{pH} 10,1 \%$ triton X 100 ) overnight in dark (so that direct light doesn't produce more DNA damage). In the final step of processing a horizontal gel electrophoresis tank was filled with electrophoresis solution $(300 \mathrm{mM}$ $\mathrm{NaOH}$, and $1 \mathrm{mM}$ EDTA, pH 12.5), and slides were placed in it with agarose end facing toward the positive terminal. The DNA fragments were separated by electrophoresis for $10 \mathrm{~min}$ at $300 \mathrm{~mA}$ and $25 \mathrm{~V}$.

For fluorescent microscopy, $100-200 \mathrm{ml}$ of $20 \mathrm{mg} / \mathrm{ml}$ acridine orange solution was overlayed by using a coverslip. The comets were analyzed using Casplab_1.2.3b2.

\subsection{Statistical analysis}

One-way analysis of variance (ANOVA) followed by Tukey's test was applied to all the experimental data for comparison of different groups by using Graphpad prism software. All the results are shown as mean \pm SEM. The significance level was set at $\mathrm{p}<0.05$.

\section{Results}

\subsection{Final weight of animals and reproductive organs}

The mean final weight of animals in the control and all experimental groups, and the weight of testis, epididymis and volume of testes showed no significant variation (Table 1 )

\subsection{Daily Sperm Production (DSP/T $\left.\times 10^{6}\right)$}

The mean value of daily sperm production in all the experimental groups showed significant change. The number of sperm in Cd treated group was significantly reduced ( $\mathrm{p}<0.001$ ), while non-significant increase was seen in co-treatment groups as compared to $\mathrm{Cd}$ group (Table 1 ). This indicates that ME plays a role in preventing (controlling) the damage caused by $\mathrm{Cd}$ to DSP. The number of sperm in the ME treated animals are significantly higher than the $\mathrm{Cd}$ treated group, but interestingly the results shows a slight decrease (non-significant) in DSP of ME treated group as compared to the Control. (Table 1 )

\subsection{Protective effect of Morel Mushrooms against $\mathrm{Cd}$ induced Damage to heritable DNA}

Anomalies in the DNA of cauda epididymal sperms were measured by comet assay, the mean value of comet head length in $\mathrm{Cd}$ treated group showed significant ( $\mathrm{p}<0,01)$ reduction when compared to the control group while the remaining parameters showed no significant variations from the control group (table 2, figure $2 \mathrm{~b}$ )in both the cotreatment groups, no significant variations were noticed in head length of comet and percentage of DNA in head or tail (table 2). But the tail length was reduced significantly in both groups as compared to the control group $(\mathrm{p}<0.05$ for $\mathrm{Cd}+10 \mathrm{mg} / \mathrm{kg}$ extract and $\mathrm{p}<0.01$ for $\mathrm{Cd}+20 \mathrm{mg} / \mathrm{kg}$ extract) (table 2, figure $2 \mathrm{C} \& \mathrm{D}$ ). the 10 and $20 \mathrm{mg} / \mathrm{kg}$ extract treated groups showed significant variation from the remaining groups. The head length in $10 \mathrm{mg}$ extract alone group was significantly increased from $\mathrm{Cd}$ treated $(\mathrm{p}<0.001)$ and $\mathrm{Cd}+10 \mathrm{mg}$ extract treated $(\mathrm{p}<0.05)$ groups (table 2). The tail length in both the extract alone treated groups was significantly $(p<0.01)$ reduced than that in the control group, while the quantity of DNA in head was significantly increased in both these groups as compared to the control and Cd treated groups, while the tail moment was also significantly reduced in both these groups when compared to the control group (figure 1, table 2)

Table 1. Mean \pm SEM of I initial and final weight of rats, its testes and epididymis, volume of testis, and daily sperm production after treatment.

\begin{tabular}{|c|c|c|c|c|c|c|c|}
\hline \multicolumn{2}{|l|}{ Groups } & \multirow{2}{*}{$\begin{array}{c}\text { Control } \\
272.4 \pm 4.15\end{array}$} & \multirow{2}{*}{$\begin{array}{c}\text { Cd } \\
295 \pm 6.12\end{array}$} & \multirow{2}{*}{$\begin{array}{c}\mathbf{C d} \begin{array}{c}\mathbf{1 0} \mathbf{~ m g} / \mathbf{k g} \\
\text { extract }\end{array} \\
272.5 \pm 11.1\end{array}$} & \multirow{2}{*}{$\begin{array}{c}\begin{array}{c}\mathbf{C d}+20 \mathrm{mg} / \mathrm{kg} \\
\text { Extract }\end{array} \\
295 \pm 12.58\end{array}$} & \multirow{2}{*}{$\begin{array}{c}10 \mathrm{mg} / \mathrm{kg} \\
\text { extract alone }\end{array}$} & \multirow{2}{*}{$\begin{array}{c}\begin{array}{c}20 \mathrm{mg} / \mathrm{kg} \\
\text { extract alone }\end{array} \\
271.25 \pm 6.57\end{array}$} \\
\hline Weight & initial & & & & & & \\
\hline & final & $288.4 \pm 4.77$ & $318.5 \pm 8.91$ & $281.5 \pm 12.8$ & $306 \pm 44.84$ & $308.5 \pm 3.22$ & $297.5 \pm 3.86$ \\
\hline \multirow{2}{*}{$\begin{array}{l}\text { weight of testis } \\
\text { (gm) }\end{array}$} & right & $1.29 \pm 0.03$ & $1.19 \pm 0.16$ & $1.05 \pm 0.17$ & $1.08 \pm 0.11$ & $1.28 \pm 0.03$ & $1.19 \pm 0.3$ \\
\hline & left & $1.28 \pm 0.03$ & $1.15 \pm 0.17$ & $0.86 \pm 0.24$ & $1.26 \pm 0.11$ & $1.31 \pm 0.04$ & $1.13 \pm 0.14$ \\
\hline \multirow{2}{*}{$\begin{array}{l}\text { Volume of } \\
\text { testis }\left(\mathrm{ml}^{3}\right)\end{array}$} & right & $1.5 \pm 0.2$ & $1.52 \pm 0.26$ & $1.12 \pm 0.29$ & $1.25 \pm 0.22$ & $1.7 \pm 0.0 .8$ & $1.75 \pm 0.08$ \\
\hline & left & $1.5 \pm 0.2$ & $1.37 \pm 0.16$ & $1.27 \pm 0.31$ & $1.41 \pm 0.19$ & $1.57 \pm 0.22$ & $1.5 \pm 0.15$ \\
\hline \multirow{2}{*}{$\begin{array}{l}\text { weight of } \\
\text { epididymis }\end{array}$} & right & $0.45 \pm 0.05$ & $0.58 \pm 0.02$ & $0.47 \pm 0.03$ & $0.45 \pm 0.02$ & $0.45 \pm 0.02$ & $0.66 \pm 0.22$ \\
\hline & left & $0.44 \pm 0.04$ & $0.51 \pm 0.03$ & $0.5 \pm 0.03$ & $0.48 \pm 0.02$ & $0.47 \pm 0.01$ & $0.69 \pm 0.23$ \\
\hline \multicolumn{2}{|c|}{$\operatorname{DSP}\left(\times 10^{6}\right)$} & $14.5 \pm 0.29$ & $3.6 \pm 1.6^{\mathrm{a} * * *}$ & $6.2 \pm 1.3^{\mathrm{a}^{*}}$ & $5.6 \pm 0.8^{\mathrm{a} * * *}$ & $9.06 \pm 1.6^{b^{*}}$ & $8.1 \pm 0.8^{\mathrm{b}^{*}}$ \\
\hline
\end{tabular}

(All values are expressed as Mean $\pm \mathrm{SEM}^{*}=\mathrm{P}<0.05,{ }^{* * *} \mathrm{P}<0.001, \mathrm{a}=$ comparison to control, $\mathrm{b}=$ comparison to $\mathrm{Cd}$ group ). 
Table 2. DNA damage as expressed by different parameters in control, Cadmium, $\mathrm{Cd}+10 \mathrm{mg}$ of extract, $\mathrm{Cd}+20 \mathrm{mg}$ extract, $10 \mathrm{mg}$ extract and $20 \mathrm{mg}$ extract treated groups.

\begin{tabular}{|c|c|c|c|c|c|}
\hline Parameters & Head length $(\mu \mathrm{m})$ & Tail length $(\mu \mathrm{m})$ & \%DNA in Head & \%DNA in Tail & Tail moment \\
\hline Control & $158.70 \pm 6.43$ & $30.65 \pm 1.92$ & $90.24 \pm 0.72$ & $10.84 \pm 3.21$ & $3.60 \pm 0.53$ \\
\hline Cadmium & $114.80 \pm 7.35^{\mathrm{a}^{\mathrm{a} *}}$ & $24.96 \pm 2.35$ & $88.94 \pm 1.64$ & $10.85 \pm 1.33$ & $2.76 \pm 0.38$ \\
\hline CD+10mg extract & $130.00 \pm 7.45$ & $19.96 \pm 2.29^{\mathrm{a}^{*}}$ & $91.97 \pm 1.31$ & $7.19 \pm 0.68$ & $1.93 \pm 0.43$ \\
\hline Cd + 20mg extract & $139.20 \pm 11.63$ & $15.78 \pm 2.137^{\mathrm{a}^{* *}}$ & $93.59 \pm 0.75^{b^{*}}$ & $6.45 \pm 0.73$ & $1.42 \pm 0.42^{\mathrm{a}^{*}}$ \\
\hline $10 \mathrm{mg}$ extract alone & $171.90 \pm 9.74^{\mathrm{b} * * * c^{*}}$ & $17.94 \pm 2.01^{\mathrm{a}^{* *}}$ & $94.62 \pm 0.50^{\mathrm{a}^{*+*} \mathrm{~b}^{+*}}$ & $5.01 \pm 0.43^{\mathrm{b}^{* *}}$ & $1.42 \pm 0.26^{\mathrm{a}^{* *}}$ \\
\hline $20 \mathrm{mg}$ extract alone & $127.80 \pm 7.32^{2^{e *}}$ & $15.82 \pm 2.10^{\mathrm{a}^{* * *} \mathrm{~b}^{*}}$ & $94.49 \pm 0.58^{\mathrm{a}^{* \mathrm{~b}} \mathrm{b*}}$ & $5.45 \pm 0.48^{\mathrm{b}^{* *}}$ & $1.15 \pm 0.33^{\mathrm{a}^{* *} \mathrm{~b}^{*}}$ \\
\hline
\end{tabular}

(All values are expressed as Mean $\pm \mathrm{SEM})\left({ }^{*}=\mathrm{P}<0.05,{ }^{* *} \mathrm{P}<0.01,{ }^{* * *} \mathrm{P}<0.001\right)(\mathrm{a}=$ control, $\mathrm{b}=$ cadmium, $\mathrm{c}=\mathrm{Cd}+10 \mathrm{mg}$ extract, $\mathrm{d}=\mathrm{Cd}+20 \mathrm{mg}$ extract, $\mathrm{e}=10 \mathrm{mg}$ extract alone).
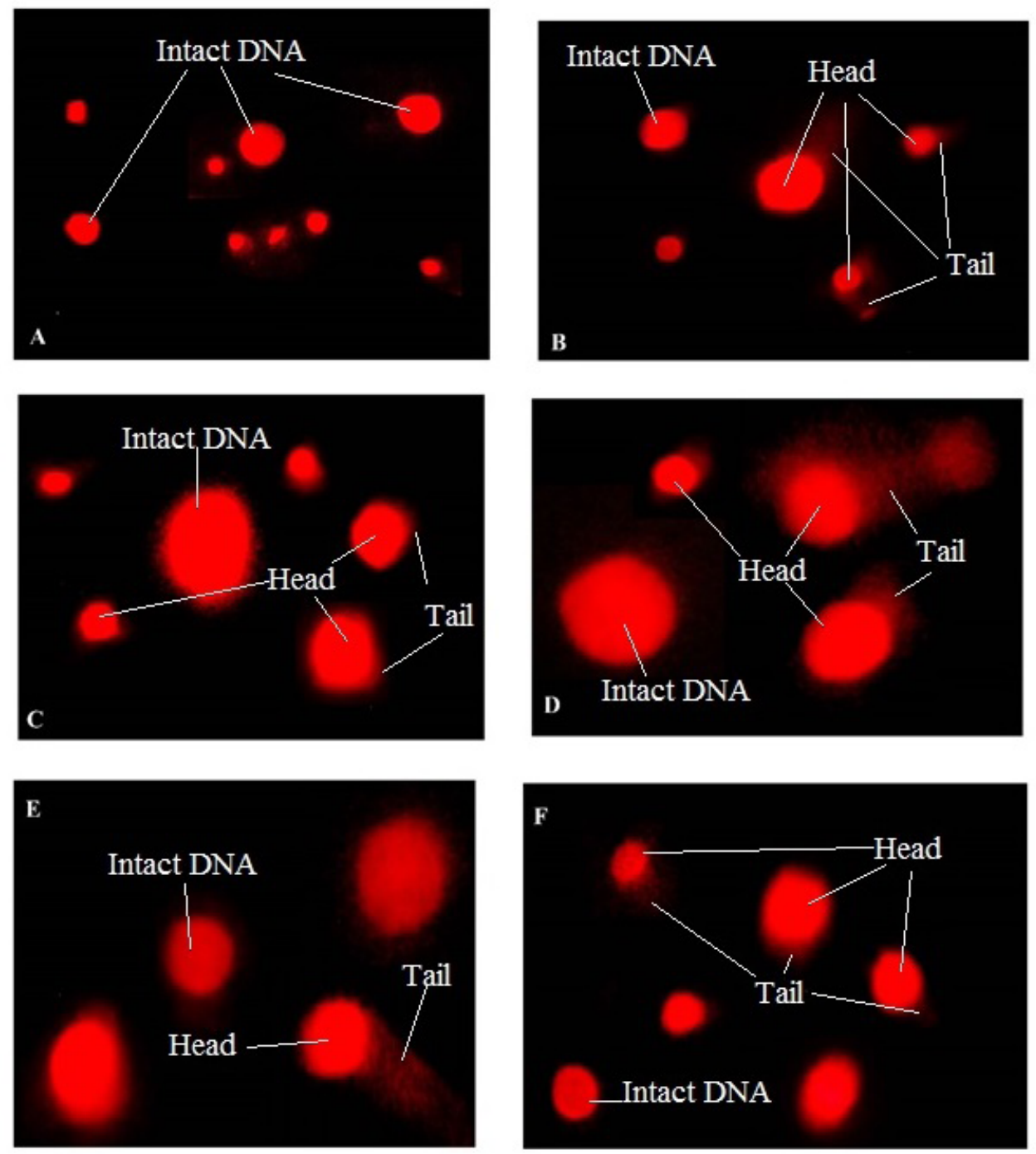

Figure 2. Fluorescent photomicrograph of sperm DNA, using comet assay, stained with acridine orange. (A) control with more intact DNA; (B) cadmium group with comets; (C) Cd $+10 \mathrm{mg}$ extract group showing intact DNA with a very short tail length; (D) Cd $+20 \mathrm{mg}$ extract group having tail of long length and intact DNA; (E) $10 \mathrm{mg}$ extract alone group in which a tail could be notice but very lesser DNA damage was found; (F) 20 mg extract alone group having short tails and intact DNA. 


\subsection{Protective Effect of Morel Mushroom Against Cd induced Histopathological Changes}

\subsubsection{Testicular tissue}

Parameters studied in testicular histology include the mean length of interstitial space, height of tunica albuginea, height of epithelium and diameter of seminiferous tubules and luminal diameter. All the tubules (in all 6 groups) could be devided into different categories based on there morphological appearance. We broadly devided all the tubules into 2 categories, first showing the first half (stage 1 to 8 ) of spermatogenesis, and 2nd showing final half of spermatogenesis (stage 9-14). Table 3 is representing the average values of all the tubules, where we observed significant variation in all 5 parameters when we compared the Cd treated group, to control group, the interstitial space and lumen of the tubules was increased significantly $(p<0.001)$, while the remaining three parameters showed significant reduction (Table 3 , figure $3 \mathrm{~b}$ ). In both co-treatment groups, the interstitial space was similar to the control group, but significantly $(\mathrm{p}<0.001)$ increased from the Cd treated group. similarly, the thickness of tunica albuginea and diameter of the seminiferous tubules in co-treated groups were decreased $(p<0.001)$ than the control group, but significantly $(\mathrm{p}<0.001)$ increased than the $\mathrm{Cd}$ treated group. The change in histological parameters of the extract treated groups were similar to the co-treatment groups (figure $3 \mathrm{E} \& \mathrm{~F}$, Table 3).
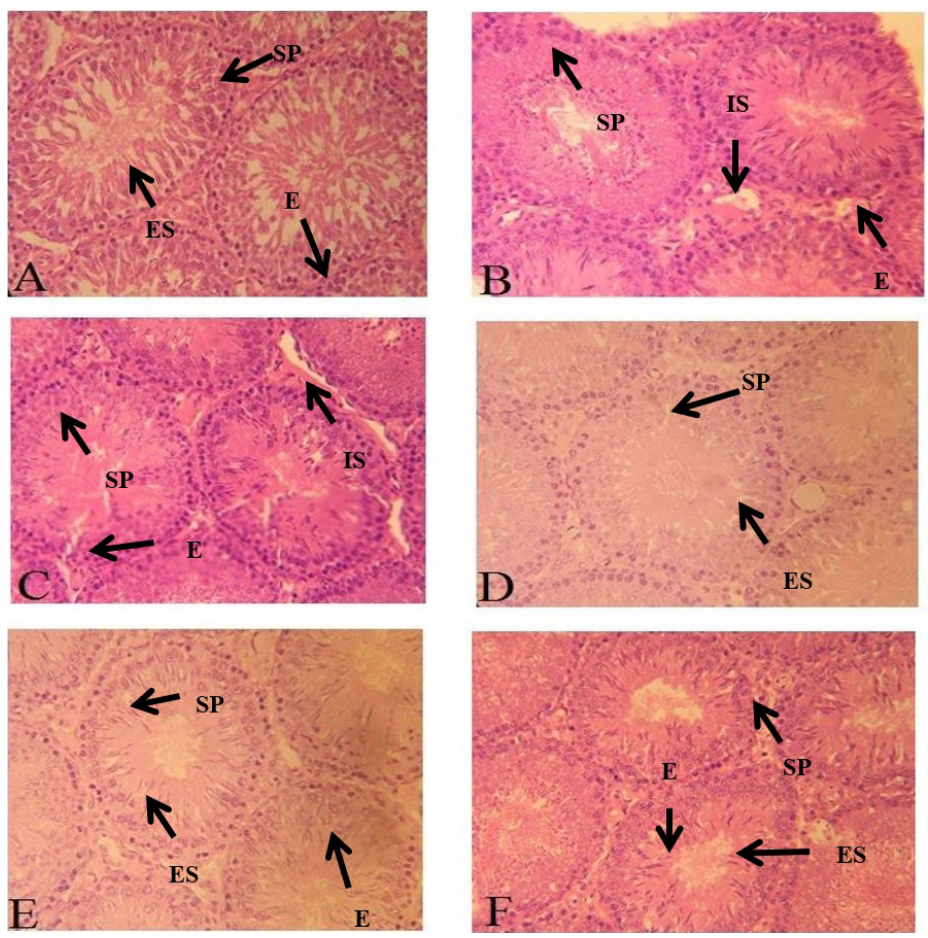

Figure 3. Photomicrograph of seminiferous tubules. (A) Control; showing compact tubules, filled lumen with spermatid, normal germ cell proliferation along epithelium; (B) Cd treated group; showing tubules with empty lumen and degenerated epithelial layer with increased interstitial space; (C) Cd+10 mg extract treated group \& (D) Cd+ $20 \mathrm{mg}$ extract treated group; showing minimal damage to epithelium, lumen filled with spermatid and less interstitial space; (E) $10 \mathrm{mg}$ extract alone group and (F) $20 \mathrm{mg}$ extract alone group; showing narrow lumen, increased epithelial height and compact tubules with less interstitial space. Magnification x40. Spermatogonia (SP), Elongated spermatids (ES), Interstitial space (IS), Epithelium (E).

Table 3. Mean \pm SEM of interstitial space $(\mu \mathrm{m})$, tunica albugenia height $(\mu \mathrm{m})$, seminiferous tubule diameter $(\mu \mathrm{m})$, epithelial height ( $\mu \mathrm{m})$ and tubular lumen $(\mu \mathrm{m})$ of rat's testis in control, Cadmium, $C d+10 \mathrm{mg}$ of extract, $C \mathrm{Cd}+20 \mathrm{mg}$ extract, $10 \mathrm{mg}$ extract and $20 \mathrm{mg}$ extract treated groups.

\begin{tabular}{|c|c|c|c|c|c|}
\hline Group & $\begin{array}{c}\text { Interstitial space } \\
(\mu \mathrm{m})\end{array}$ & $\begin{array}{c}\text { Tunica albugenia } \\
\text { height }(\mu \mathrm{m})\end{array}$ & $\begin{array}{c}\text { seminiferous } \\
\text { tubule diameter } \\
(\mu \mathrm{m})\end{array}$ & $\begin{array}{c}\text { Epithelial height } \\
(\mu \mathrm{m})\end{array}$ & $\begin{array}{l}\text { Tubular lumen } \\
\text { diameter }(\mu \mathrm{m})\end{array}$ \\
\hline Control & $6.01 \pm 0.44$ & $31.13 \pm 1.12$ & $235.02 \pm 5.26$ & $69.65 \pm 2.20$ & $20.53 \pm 0.81$ \\
\hline Cadmium & $13.28 \pm 0.80^{\mathrm{a}^{* * * *}}$ & $20.16 \pm 1.26^{\mathrm{a}^{* * * *}}$ & $159.51 \pm 3.68^{\mathrm{a}^{* * * *}}$ & $36.86 \pm 2.78^{\mathrm{a}^{* * * *}}$ & $36.82 \pm 2.45^{\mathrm{a}^{* * *}}$ \\
\hline Cd + 10 mg ext & $5.36 \pm 0.53^{\mathrm{b} * * *}$ & $23.18 \pm 0.67^{\mathrm{a}^{* * *}}$ & $209.84 \pm 4.02^{\mathrm{ab} \mathrm{b}^{* * * *}}$ & $64.25 \pm 4.37^{\mathrm{b}^{* * * *}}$ & $23.03 \pm 1.45^{\mathrm{b}^{* * *}}$ \\
\hline $\mathrm{Cd}+20 \mathrm{mg}$ ext & $5.16 \pm 0.29^{b^{* * * *}}$ & $22.53 \pm 1.15^{\mathrm{a}^{* * *}}$ & $185.69 \pm 4.63^{\mathrm{abc}^{* * *}}$ & $59.18 \pm 3.32^{\mathrm{b}^{* * * *}}$ & $26.71 \pm 1.18^{\mathrm{b}^{* * * *}}$ \\
\hline $10 \mathrm{mg}$ ext alone & $5.78 \pm 0.30^{\mathrm{b}^{* * * *}}$ & $28.95 \pm 1.08^{\mathrm{b}^{* * *} \mathrm{~cd}^{* * *}}$ & $203.55 \pm 3.14^{\mathrm{ab}^{* * * *} \mathrm{~d} *}$ & $58.65 \pm 1.92^{\mathrm{b}^{* * * *}}$ & $24.43 \pm 1.85^{\mathrm{b}^{* * * *}}$ \\
\hline 20 mg ext alone & $5.26 \pm 0.41^{\mathrm{b}^{* * * *}}$ & $24.63 \pm 1.51^{a * *}$ & $208.67 \pm 4.07^{\mathrm{ab}^{* * * \mathrm{~d}^{* * *}}}$ & $53.25 \pm 2.83^{\mathrm{ab}^{* * *}}$ & $28.46 \pm 1.43^{\mathrm{ab}^{* * *}}$ \\
\hline
\end{tabular}

(All values are expressed as Mean $\pm \mathrm{SEM})\left({ }^{*}=\mathrm{P}<0.05,{ }^{* *} \mathrm{P}<0.01,{ }^{* * *} \mathrm{P}<0.001\right)(\mathrm{a}=$ control, $\mathrm{b}=\mathrm{cadmium}, \mathrm{c}=\mathrm{Cd}+10 \mathrm{mg}$ extract, $\mathrm{d}=$ $\mathrm{Cd}+20 \mathrm{mg}$ extract, $\mathrm{e}=10 \mathrm{mg}$ extract alone $)$. 


\subsubsection{Epididymis}

The histological analysis of caput and cauda epididymis showed that the ductular diameter along with its lumen diameter and height of the epithelium in the Cd treated group was significantly reduced as compared to all the remaining groups (figure 4 ). The co-treatment groups showed reduction in diameter of ducts and its lumen in comparison to the control, but non-significantly increase than the Cd treated group. (figure 4)
3.5 Effect of Cd and ME on blood plasma Testosterone level

The plasma testosterone level was reduced significantly $(\mathrm{p}<0.001)$ in Cd treated group as compared to the Control Group. Whereas in co-treatment groups, a decrease was noticed but only $\mathrm{Cd}+20 \mathrm{mg}$ group showed significant $\mathrm{p}<0.05$ ) change when comparison was made with control. The testosterone level in both co-treated groups was significantly $(\mathrm{p}<0.001)$ higher that $\mathrm{Cd}$ group. While the testosterone level in both the extract alone groups was slightly higher that the control group, but the difference was not significant (Figure 5).
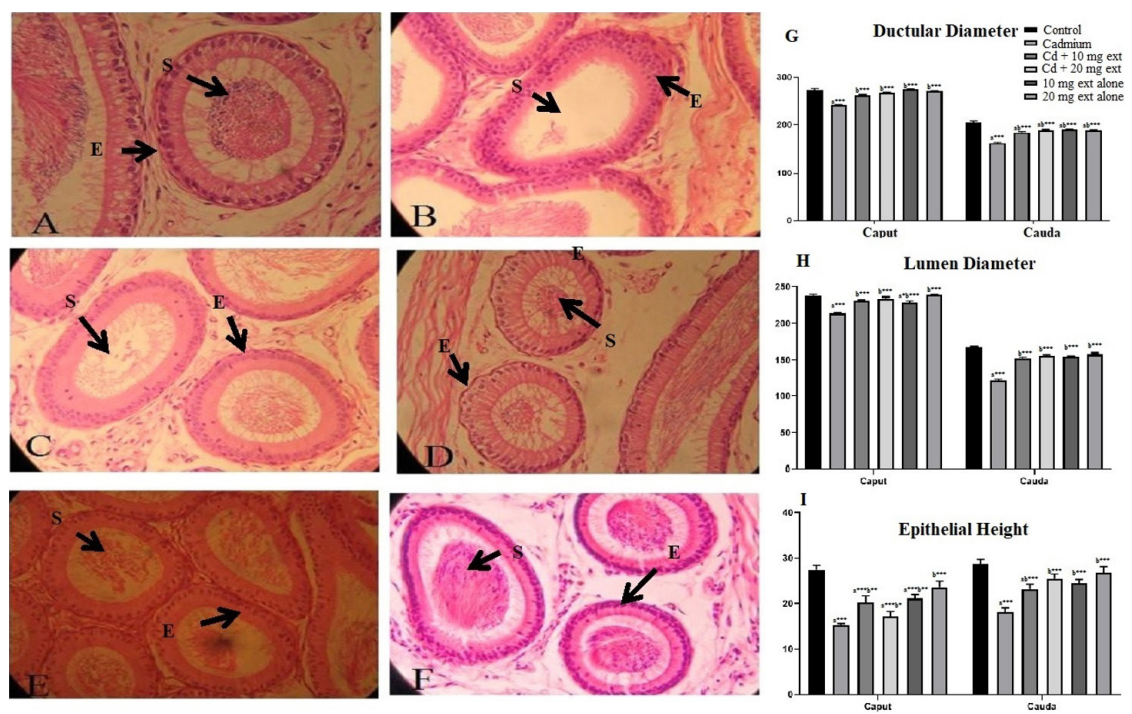

Figure 4. photomicrograph of cross section of epididymis (cauda) of rats (H\&E, 40X) from: (A) Control group; showing normal morphology of cauda epididymis showing compactly arranged tubules with thick epithelium, lumen filled with sperm; (B) Cadmium group; showing marked changes in structure of tubule with decreased concentration of sperm; (C) Cd+10 mg extract group \& (D) Cd+20 mg extract group; showing regular arrangement of tubules surrounded by stroma, lumen filled with spermatozoa; (E) $10 \mathrm{mg}$ extract alone group and (F) $20 \mathrm{mg}$ extract alone group ; showing increase in epithelium an lumen sperm concentration. Spermatozoa (S), Epithelium (E), Stroma (St). G, H and I summarizes the variations in tubule and lumen diameter and height of epithelium.

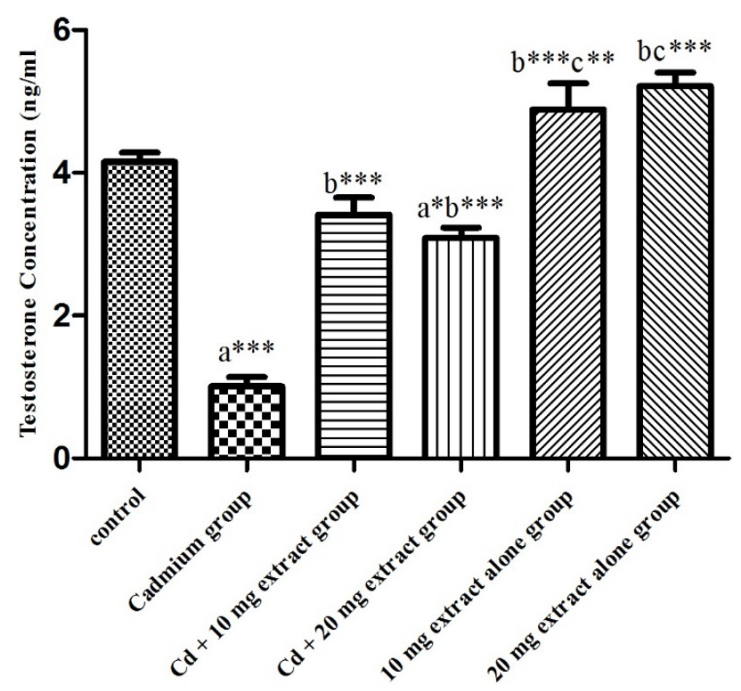

Figure 5. Mean \pm SEM of plasma testosterone $(\mathrm{ng} / \mathrm{ml})$ concentration in rats of control, Cadmium, $\mathrm{Cd}+10 \mathrm{mg}$ of extract, $\mathrm{Cd}+20 \mathrm{mg}$ extract, $10 \mathrm{mg}$ extract and $20 \mathrm{mg}$ extract group. (All values are expressed as Mean $\pm \mathrm{SEM})\left({ }^{*}=\mathrm{P}<0.05,{ }^{* *} \mathrm{P}<0.01,{ }^{* * *} \mathrm{P}<0.001, \mathrm{a}=\mathrm{control}\right.$, $\mathrm{b}=$ Cadmium, $\mathrm{c}=\mathrm{Cd}+10 \mathrm{mg}$ extract). 


\section{Discussion}

Edible Mushrooms are the source of food and medicine for centuries (Wasser, 2002). These are considered as rich source of proteins and carbohydrates (Yun and Hall, 2004). In preterit past, the water-soluble contents in mushrooms were used as medicine. Specifically, the polysaccharides in mushrooms are reported to have immunomodulating and antitumor features (Borchers et al., 1999; Wasser, 2002). The fruiting body of ME is rich in carbohydrates, protein, vitamins (B, A, C and D) and minerals, while low in calories and fat content (Mattila et al., 2001; Negi, 2006). The ME along with its dietary and pharmacological properties is also reported to be widely used for its aphrodisiac properties (Gewali, 2009; Sud and Sud, 2017). On the other side Cd is reported with opposite properties. In remote past It is suggested that different cells and pathways, are interfered by Cd particularly the pituitary-hypothalamus-gonadal pathway (Bertin and Averbeck, 2006; Cheng et al., 2019; Waisberg et al., 2003). The cell proliferation, cell cycle progression, differentiation, the process of DNA repair and replication and the apoptotic pathways are all impaired (Cheng et al., 2019; Fang et al., 2002; Oh and Lim, 2006; Yang et al., 2004).

In previous literature, contradictory results have been reported about the effect of $\mathrm{Cd}$ on weight of organisms, where some articles had reported that Cd has negative effect on weight gain of organisms (Lynch et al., 1976; Ren et al., 2019; Asagba et al., 2007), but our findings are in accordance with Bebe and Panemangalore (1996), as there was no significant difference observed in weight gain of animals treated with $\mathrm{Cd}$ and the control group (Table 1). While looking at the nutritious components of ME (Halliwell, 2012; Raman, 2018) low calories and fat content, we observed no significant difference in weight gain of all ME extract treated groups from the control group.

In current study, a vital Cd generated reproductive damage in Cd treated group was observed, but the weight of testis, epididymis and volume of testis was almost similar in all the groups. In some previous studies (El-demerdash et al., 2004; Asagba et al., 2007; Santos et al., 2006) a huge impact of $C d$ is reported on reproductive and accessory sex organs along with weight of animals, although some studies suggest no or very less change on accessory organs (Predes et al., 2010; Wade et al., 2002). These structural discrepancies are directly related to physiological problems(Sinha Hikim et al., 1988). To determine the protective effect of ME against the morphological damage caused by $\mathrm{Cd}$, histopathology of testis and epididymis was performed and clear deformities in the seminiferous tubules of Cd treated animals were noted. Similar results were reported previously in case of reproductive toxicity caused by Cd (Adamkovicova et al., 2014; Afsar et al., 2018; Sakr and Nooh, 2013; Wang et al., 2019). The co-treatment and extract alone treated groups showed interesting results as ME is never used before as treatment for heavy metal toxicity or improving the process of spermatogenesis. The use of medicinal herb and its extracts are repeatedly reported in Ayurvedic medicine (India), Unani medicine (Pakistan) and Chinese Traditional Medicine (TCM) for different purposes, (Mishra and Singh, 2016). Cd group showed expected results on DSP as discussed in earlier studies that morphological changes are directly related to physiological changes(Pires et al., 2013). Additionally, Cd induced oxidative stress which is the vital reason of decrease in DSP (Wong and Cheng, 2011). But in Co-treatment groups and ME extract alone group the sperm count is increased significantly as compared to the Cd group. According to Pires and his team, the low level of testosterone is related to injurious effects of $\mathrm{Cd}$ (Pires et al., 2013). Results of current study showed that ME not only restored the damage done by $C D$, but also enhances the production of testosterone. And this might explain why in past people used ME as an aphrodisiac medicine.

\section{Conclusion}

The current study provides an evidence that ME control the damages caused by acute exposure of $\mathrm{Cd}$ to testicular tissue. But further study is require to select proper dose to completely control the damage. In past ME is used for its aphrodisiac properties, in current study the results of testosterone level could explain the aphrodisiac properties of ME. But further study are required in this regard.The results of this study explain the potential prospects of ME for the treatment of heavy metal toxicity.

\section{Future Prospects}

Based on findings of this article, the effects of ME on different reproductive system pathways including pituitary-hypothalamus-gonadal axis should be studied. This study provides basis for herbal treatment of reproductive impairments caused by heavy metals. Further studies are required to find underlying metabolic pathways and molecular mechanisms adopted by ME extract affecting reproduction.

\section{Acknowledgements}

This work was supported by the National Natural Science Foundation of China (31772596, 31872983 and 31672417); Jilin Key Program for Science and Technology Development (201903011008NY).

\section{References}

ADAMKOVICOVA, M., TOMAN, R., CABAJ, M., MASSANYI, P., MARTINIAKOVA, M., OMELKA, R., KRAJCOVICOVA, V. and DURANOVA, H., 2014. Effects of subchronic exposure to cadmium and diazinon on testis and epididymis in rats. TheScientificWorldJournal, vol. 2014, pp. 632581. http://dx.doi. org/10.1155/2014/632581. PMid:25548789.

AFSAR, T., RAZAK, S., ALMAJWAL, A. and KHAN, M.R., 2018. Acacia hydaspica R. Parker ameliorates cisplatin induced oxidative stress, DNA damage and morphological alterations in rat pulmonary tissue. BMC Complementary and Alternative Medicine, vol. 18, no. 1, pp. 1-13. http://dx.doi.org/10.1186/s12906-0182113-0. PMid:29394892. 
AHMAD, L., JALALI, S., SHAMI, S.A. and AKRAM, Z., 2007. Sperm preparation: DNA damage by comet assay in normo- and teratozoospermics. Archives of Andrology, vol. 53, no. 6, pp. 325-338. http://dx.doi.org/10.1080/01485010701730963. PMid:18357962.

ASAGBA, S.O., ADAIKPOH, M.A., KADIRI, H. and OBI, F.O., 2007. Influence of aqueous extract of Hibiscus sabdariffa $L$. petal on cadmium toxicity in rats. Biological Trace Element Research, vol. 115, no. 1, pp. 47-57. PMid: 17406073.

BAATI, T., HORCAJADA, P., GREF, R., COUVREUR, P. and SERRE, C., 2011. Quantification of fumaric acid in liver, spleen and urine by high-performance liquid chromatography coupled to photodiode-array detection. Journal of Pharmaceutical and Biomedical Analysis, vol. 56, no. 4, pp. 758-762. http://dx.doi. org/10.1016/j.jpba.2011.07.011. PMid:21820831.

BEBE, F.N. and PANEMANGALORE, M., 1996. Modulation of tissue trace metal concentrations in weanling rats fed different levels of zinc and exposed to oral lead and cadmium. Nutrition Research, vol. 16, no. 8, pp. 1369-1380. https://doi.org/10.1016/j. fct.2004.05.001.

BECKER, S. and BERHANE, K., 1997. A meta-analysis of 61 sperm count studies revisited. Fertility and Sterility, vol. 67, no. 6, pp. 1103-1108. http://dx.doi.org/10.1016/S0015-0282(97)81446-X. PMid:9176451.

BENOFF, S., JACOB, A. and HURLEY, I.R., 2000. Male infertility and environmental exposure to lead and cadmium. Human Reproduction Update, vol. 6, no. 2, pp. 107-121. http://dx.doi. org/10.1093/humupd/6.2.107. PMid:10782569.

BERNARD, A., 2008. Cadmium \& its adverse effects on human health. The Indian Journal of Medical Research, vol. 128, no. 4, pp. 557-564. PMid:19106447.

BERTIN, G. and AVERBECK, D., 2006. Cadmium: cellular effects, modifications of biomolecules, modulation of DNA repair and genotoxic consequences (a review). Biochimie, vol. 88, no. 11, pp. 1549-1559. http://dx.doi.org/10.1016/j.biochi.2006.10.001. PMid:17070979.

BORCHERS, A.T., STERN, J.S., HACKMAN, R.M., KEEN, C.L. and GERSHWIN, M.E., 1999. Mushrooms, tumors, and immunity. Proceedings of the Society for Experimental Biology and Medicine, vol. 221, no. 4, pp. 281-293.

CASALINO, E., SBLANO, C. and LANDRISCINA, C., 1997. Enzyme activity alteration by cadmium administration to rats: the possibility of iron involvement in lipid peroxidation. Archives of Biochemistry and Biophysics, vol. 346, no. 2, pp. 171-179. https://doi.org/10.1006/abbi.1997.0197.

CASALINO, E., CALZARETTI, G., SBLANO, C. and LANDRISCINA, C., 2000. Cadmium-dependent enzyme activity alteration is not imputable to lipid peroxidation. Archives of Biochemistry and Biophysics, vol. 383, no. 2, pp. 288-295. http://dx.doi.org/10.1006/ abbi.2000.2056. PMid:11185565.

CASALINO, E., CALZARETTI, G., SBLANO, C. and LANDRISCINA, C., 2002. Molecular inhibitory mechanisms of antioxidant enzymes in rat liver and kidney by cadmium. Toxicology, vol. 179, no. 1-2, pp. 37-50. http://dx.doi.org/10.1016/S0300-483X(02)00245-7. PMid:12204541.

CHAN, H.M. and CHERIAN, M.G., 1992. Protective roles of metallothionein and glutathione in hepatotoxicity of cadmium. Toxicology, vol. 72, no. 3, pp. 281-290. http://dx.doi. org/10.1016/0300-483X(92)90179-I. PMid:1585382.

CHENG, Y., ZHANG, J., WU, T., JIANG, X., JIA, H., QING, S., AN, Q., ZHANG, Y. and SU, J., 2019. Reproductive toxicity of acute Cd exposure in mouse: resulting in oocyte defects and decreased female fertility. Toxicology and Applied Pharmacology, vol. 379, pp. 114684. http://dx.doi.org/10.1016/j.taap.2019.114684. PMid:31325558.

ÇILENK, K.T., ÖZTÜRK, İ. and SÖNMEZ, M.F., 2016. Ameliorative effect of propolis on the cadmium-induced reproductive toxicity in male albino rats. Experimental and Molecular Pathology, vol. 101, no. 2, pp. 207-213. http://dx.doi.org/10.1016/j. yexmp.2016.08.004. PMid:27587086.

COOGAN, T.P., BARE, R.M. and WAALKES, M.P., 1992. Cadmiuminduced DNA strand damage in cultured liver cells: reduction in cadmium genotoxicity following zinc pretreatment. Toxicology and Applied Pharmacology, vol. 113, no. 2, pp. 227-233. http:// dx.doi.org/10.1016/0041-008X(92)90118-C. PMid:1561631.

DANIELSSON, B.R.G., DENCKER, L., LINDGREN, A. and TJÄLVE, H., 1984. Accumulation of toxic metals in male reproduction organs. In: P.L. CHAMBERS, P. PREZIOSI and C.M. CHAMBERS, eds. Disease, metabolism and reproduction in the toxic response to drugs and other chemicals. archives of toxicology. Berlin, Heidelberg: Springer, pp. 177-180.

DUNCAN, C.J.G., PUGH, N., PASCO, D.S. and ROSS, S.A., 2002. Isolation of a galactomannan that enhances macrophage activation from the edible fungus Morchella esculenta. Journal of Agricultural and Food Chemistry, vol. 50, no. 20, pp. 5683-5685. http:// dx.doi.org/10.1021/jf020267c. PMid:12236698.

EL-DEMERDASH, F.M., YOUSEF, M.I., KEDWANY, F.S. and BAGHDADI, H.H., 2004. Cadmium-induced changes in lipid peroxidation, blood hematology, biochemical parameters and semen quality of male rats: protective role of vitamin $\mathrm{E}$ and $\beta$-carotene. Food and Chemical Toxicology, vol. 42, no. 10, pp. 1563-1571. https:// doi.org/10.1016/j.fct.2004.05.001.

ELMASTAS, M., TURKEKUL, I., OZTURK, L., GULCIN, I., ISILDAK, O. and ABOUL-ENEIN, H., 2006. Antioxidant activity of two wild edible mushrooms (Morchella vulgaris and Morchella esculanta) from North Turkey. Combinatorial Chemistry \& High Throughput Screening, vol. 9, no. 6, pp. 443-448. http://dx.doi. org/10.2174/138620706777698544. PMid:16842225.

FANG, M., MAR, W. and CHO, M., 2002. Cadmium affects genes involved in growth regulation during two-stage transformation of Balb / 3T3 cells 177. Toxicology, vol. 177, no. 2-3, pp. 253-265. https://doi.org/10.1016/s0300-483x(02)00229-9.

FAROON, O., ASHIZAWA, A., WRIGHT, S., TUCKER, P., JENKINS, K., INGERMAN, L. and RUDISILL, C., 2012. Toxicological profile for cadmium, Agency for Toxic Substances and Disease Registry (ATSDR) toxicological profiles. Atlanta: Agency for Toxic Substances and Disease Registry.

FISCH, H. and GOLUBOFF, E.T., 1996. Geographic variations in sperm counts: a potential cause of bias in studies of semen quality. Fertility and Sterility, vol. 65, no. 5, pp. 1044-1046. http://dx.doi. org/10.1016/S0015-0282(16)58284-3. PMid:8612832.

GEWALI, M.B., 2009. Studies on the most traded medicinal plants from the Dolpa District of Nepal. Toyama: University of Toyama Repository, pp. 1-28.

GOERING, P.L., FISHER, B.R. and KISH, C.L., 1993. Stress protein synthesis induced in rat liver by cadmium precedes hepatotoxicity. Toxicology and Applied Pharmacology, vol. 122, no. 1, pp. 139-148. http://dx.doi.org/10.1006/taap.1993.1181. PMid:8378928.

HALLIWELL, B., 2011. Free radicals and antioxidants - Quo vadis? Trends in Pharmacological Sciences, vol. 32, no. 3, pp. 125-130. http://dx.doi.org/10.1016/j.tips.2010.12.002. PMid:21216018.

HALLIWELL, B., 2012. Free radicals and antioxidants: updating a personal view. Nutrition Reviews, vol. 70, no. 5, pp. 257265. http://dx.doi.org/10.1111/j.1753-4887.2012.00476.x. PMid:22537212. 
HELENO, S.A., STOJKOVIĆ, D., BARROS, L., GLAMOČLIJA, J., SOKOVIĆ, M., MARTINS, A., QUEIROZ, M.J.R.P. and FERREIRA, I.C.F.R., 2013. A comparative study of chemical composition, antioxidant and antimicrobial properties of Morchella esculenta (L.) Pers. from Portugal and Serbia. Food Research International, vol. 51, no. 1, pp. 236-243. http://dx.doi.org/10.1016/j.foodres.2012.12.020.

HUSSAIN, T., SHUKLA, G.S. and CHANDRA, S.V., 1987. Effects of cadmium on superoxide dismutase and lipid peroxidation in liver and kidney of growing rats: in vivo and in vitro studies. Pharmacology \& Toxicology, vol. 60, no. 5, pp. 355-358. http:// dx.doi.org/10.1111/j.1600-0773.1987.tb01526.x. PMid:3615346.

IQBAL, T., CAO, M., ZHAO, Z., ZHAO, Y., CHEN, L., CHEN, T., LI, C. and ZHOU, X., 2021. Damage to the testicular structure of rats by acute oral exposure of cadmium. International Journal of Environmental Research and Public Health, vol. 18, no. 11, pp. 6038. http://dx.doi.org/10.3390/ijerph18116038. PMid:34199704.

ISLAM, M.A., ROMIĆ, D., AKBER, M.A. and ROMIĆ, M., 2018. Trace metals accumulation in soil irrigated with polluted water and assessment of human health risk from vegetable consumption in Bangladesh. Environmental Geochemistry and Health, vol. 40, no. 1, pp. 59-85. http://dx.doi.org/10.1007/s10653-017-9907-8. PMid:28101717.

JAHAN, S., REHMAN, S., ULLAH, H., MUNAWAR, A., AIN, Q.U. and IQBAL, T., 2016. Ameliorative effect of quercetin against arsenicinduced sperm DNA damage and daily sperm production in adult male rats. Drug and Chemical Toxicology, vol. 39, no. 3, pp. 290-296. http://dx.doi.org/10.3109/01480545.2015.11017 72. PMid:26524343.

JÄRUP, L. and ÅKESSON, A., 2009. Current status of cadmium as an environmental health problem. Toxicology and Applied Pharmacology, vol. 238, no. 3, pp. 201-208. http://dx.doi. org/10.1016/j.taap.2009.04.020. PMid:19409405.

JAY, D., ZAMORANO, R., MUÑOZ, E., GLEASON, R. and BOLDU, J.L., 1991. Study of the interaction of cadmium with membranebound succinate dehydrogenase. Journal of Bioenergetics and Biomembranes, vol. 23, no. 2, pp. 381-389. http://dx.doi. org/10.1007/BF00762229. PMid:2050657.

KRZYZANOWSKI, M. and COHEN, A., 2008. Update of WHO air quality guidelines. Air Quality, Atmosphere \& Health, vol. 1, no. 1, pp. 7-13. http://dx.doi.org/10.1007/s11869-008-0008-9.

LI, P., LIN, C., CHENG, H., DUAN, X. and LEI, K., 2015. Contamination and health risks of soil heavy metals around a lead/zinc smelter in southwestern China. Ecotoxicology and Environmental Safety, vol. 113, pp. 391-399. http://dx.doi.org/10.1016/j. ecoenv.2014.12.025. PMid:25540851.

LI, W., ZHAO, Y. and CHOU, I.N.. 1993. Alterations in cytoskeletal protein sulfhydryls and cellular glutathione in cultured cells exposed to cadmium and nickel ions. Toxicology, vol. 77, no. 1-2, pp. 65-79. http://dx.doi.org/10.1016/0300-483X(93)90138-I. PMid:8442019.

LI, X., LIU, J., WU, S., ZHENG, W., LI, H., BAO, S., CHEN, Y., GUO, X., ZHANG, L. and GE, R.S., 2018. In utero single low-dose exposure of cadmium induces rat fetal Leydig cell dysfunction. Chemosphere, vol. 194, pp. 57-66. http://dx.doi.org/10.1016/j. chemosphere.2017.11.159. PMid:29197250.

LYNCH, G.P., SMITH, D.F.I., FISHER, M., PIKE, T.L. and WEINLAND, B.T., 1976. Physiological responses of calves to cadmium and lead.Journal of Animal Science, vol. 42, no. 2, pp. 410-421. http:// dx.doi.org/10.2527/jas1976.422410x.

MANCA, D., RICARD, A.C., TROTTIER, B. and CHEVALIER, G., 1991. Studies on lipid peroxidation in rat tissues following administration of low and moderate doses of cadmium chloride. Toxicology, vol. 67, no. 3, pp. 303-323. http://dx.doi. org/10.1016/0300-483X(91)90030-5. PMid:1828634.

MATTILA, P., KÖNKÖ, K., EUROLA, M., PIHLAVA, J.M., ASTOLA, J., VAHTERISTO, L., HIETANIEMI, V., KUMPULAINEN, J., VALTONEN, M. and PIIRONEN, V., 2001. Contents of vitamins, mineral elements, and some phenolic compounds in cultivated mushrooms. Journal of Agricultural and Food Chemistry, vol. 49, no. 5, pp. 2343-2348. http://dx.doi.org/10.1021/jf001525d. PMid:11368601.

MENG, F., ZHOU, B., LIN, R., JIA, L., LIU, X., DENG, P., FAN, K., WANG, G., WANG, L. and ZHANG, J., 2010. Extraction optimization and in vivo antioxidant activities of exopolysaccharide by Morchella esculenta SO-01. Bioresource Technology, vol. 101, no. 12, pp. 4564-4569. http://dx.doi.org/10.1016/j.biortech.2010.01.113. PMid:20153962.

MISHRA, R.K. and SINGH, S.K., 2016. Biphasic effect of Syzygium aromaticum flower bud on reproductive physiology of male mice. Andrologia, vol. 48, no. 9, pp. 923-932. http://dx.doi. org/10.1111/and.12533. PMid:26840772.

MÜLLER, L., 1986. Consequences of cadmium toxicity in rat hepatocytes: mitochondrial dysfunction and lipid peroxidation. Toxicology, vol. 40, no. 3, pp. 285-295. http://dx.doi. org/10.1016/0300-483X(86)90061-2. PMid:3750329.

NEGI, C., 2006. Morels (Morchella spp.) in Kumaun Himalaya. Indian Journal of Natural Products and Resources, vol. 5, no. 4, pp. 306-310.

NITHA, B. and JANARDHANAN, K.K., 2008. Aqueous-ethanolic extract of morel mushroom mycelium Morchella esculenta, protects cisplatin and gentamicin induced nephrotoxicity in mice. Food and Chemical Toxicology, vol. 46, no. 9, pp.3193-3199. http://dx.doi.org/10.1016/j.fct.2008.07.007. PMid:18692113.

NITHA, B., DE, S., ADHIKARI, S.K., DEVASAGAYAM, T.P.A. and JANARDHANAN, K.K., 2010. Evaluation of free radical scavenging activity of morel mushroom, Morchella esculenta mycelia: A potential source of therapeutically useful antioxidants. Pharmaceutical Biology, vol. 48, no. 4, pp. 453-460. http://dx.doi. org/10.3109/13880200903170789. PMid:20645726.

$\mathrm{OH}, \mathrm{S}$. and LIM, S., 2006. A rapid and transient ROS generation by cadmium triggers apoptosis via caspase-dependent pathway in HepG2 cells and this is inhibited through $\mathrm{N}$ -acetylcysteine-mediated catalase upregulation. Toxicology and Applied Pharmacology, vol. 212, no. 3, pp. 212-223. https:// doi.org/10.1016/j.taap.2005.07.018.

OLDEREID, N.B., THOMASSEN, Y., ATTRAMADAL, A., OLAISEN, B. and PURVIS, K., 1993. Concentrations of lead, cadmium and zinc in the tissues of reproductive organs of men. Journal of Reproduction and Fertility, vol. 99, no. 2, pp. 421-425. http:// dx.doi.org/10.1530/jrf.0.0990421. PMid:8107024.

PAULSEN, C.A., BERMAN, N.G. and WANG, C., 1996. Data from men in greater Seattle area reveals no downward trend in semen quality: further evidence that deterioration of semen quality is not geographically uniform. Fertility and Sterility, vol. 65, no. 5, pp. 1015-1020. http://dx.doi.org/10.1016/s00150282(16)58279-X. PMid:8612827.

PIRES, V.C., GOLLÜCKE, A.P.B., RIBEIRO, D.A., LUNGATO, L., D'ALMEIDA, V. and AGUIAR JUNIOR, O., 2013. Grape juice concentrate protects reproductive parameters of male rats against cadmium-induced damage: a chronic assay. The British Journal of Nutrition, vol. 110, no. 11, pp. 2020-2029. http://dx.doi. org/10.1017/S0007114513001360. PMid:23656754.

PREDES, F.D.S., DIAMANTE, M.A.S. and DOLDER, H., 2010. Testis response to low doses of cadmium in Wistar rats. International 
Journal of Experimental Pathology, vol. 91, no. 2, pp. 125-131. https://doi.org/10.1111/j.1365-2613.2009.00692.x.

QING, X., YUTONG, Z. and SHENGGAO, L., 2015. Assessment of heavy metal pollution and human health risk in urban soils of steel industrial city (Anshan), Liaoning, Northeast China. Ecotoxicology and Environmental Safety, vol. 120, pp. 377-385. http://dx.doi.org/10.1016/j.ecoenv.2015.06.019. PMid:26114257.

RAFATI RAHIMZADEH, M., RAFATI RAHIMZADEH, M., KAZEMI, S., and MOGHADAMNIA, A.A., 2017. Cadmium toxicity and treatment: an update. Caspian Journal of Internal Medicine, vol. 8, no. 3, pp. 135-145. http://dx.doi.org/10.22088/cjim.8.3.135. PMid:28932363.

RAGAN, H.A. and MAST, T.J., 1990. Cadmium inhalation and male reproductive toxicity. In: G.W. WARE, ed. Reviews of environmental contamination and toxicology. USA: Springer, pp. 1-22. http://dx.doi.org/10.1007/978-1-4612-3368-8_1.

RAMAN, V.K., 2018. Morchella Esculenta: a herbal boon to pharmacology. International Journal of Development Research, vol. 8, no. 3, pp. 19660-19665.

RAMELLI, G.P., TADDEO, I., HERRMANN, U. and WEBER, P., 2009 V13 Poster location 013 Paroxysmal tonic upgaze of infancy: 5 additional cases. European Journal of Paediatric Neurology, vol. 13, suppl. 1, pp. S10. http://dx.doi.org/10.1016/S10903798(09)70033-9.

REN, Y., SHAO, W., ZUO, L., ZHAO, W., QIN, H., HUA, Y., LU, D., MI, C., ZENG, S. and ZU, L., 2019. Mechanism of cadmium poisoning on testicular injury in mice. Ondology Letters, vol. 18, no. 2, pp. 1035-1042. https://doi.org/10.3892/ol.2019.10418.

ROBB, G.W., AMANN, R.P. and KILLIAN, G.J., 1978. Daily sperm production and epididymal sperm reserves of pubertal and adult rats. Journal of Reproduction and Fertility, vol. 54, no. 1, pp. 103-107. http://dx.doi.org/10.1530/jrf.0.0540103. PMid:712697.

SAKR, S.A. and NOOH, H.Z., 2013. Effect of Ocimum basilicum extract on cadmium-induced testicular histomorphometric and immunohistochemical alterations in albino rats. Anatomy \& Cell Biology, vol. 46, no. 2, pp. 122-130. http://dx.doi.org/10.5115/ acb.2013.46.2.122. PMid:23869259.

SANTOS, F.W., GRAC, D.L., ZENI, G., WEIS, S.N., FAVERO, A.M. and NOGUEIRA, C.W., 2006. Sub-chronic administration of diphenyl diselenide potentiates cadmium-induced testicular damage in mice. Reproductive Toxicology, vol. 22, no. 3, pp. 546-550. https://doi.org/10.1016/j.reprotox.2005.12.009.

SHUKLA, G.S., HUSSAIN, T. and CHANDRA, S.V., 1987. Possible Role of Regional Superoxide Dismutase Activity and Lipid. Life Sciences, vol. 41, no. 19, pp. 2215-2221. http://dx.doi.org/10.1016/00243205(87)90518-2. PMid:3669920.

SINHA HIKIM, A.P., BARTKE, A. and RUSSELL, L.D., 1988. Morphometric studies on hamster testes in gonadally active and inactive states: light microscope findings. Biology of Reproduction, vol. 39, no. 5, pp. 1225-1237. http://dx.doi. org/10.1095/biolreprod39.5.1225. PMid:3219392.

ŠRÁM, R.J., BENEŠ, I., BINKOVÁ, B., DEJMEK, J., HORSTMAN, D., KOTĚŠOVEC, F., OTTO, D., PERREAULT, S.D., RUBEŠ, J., SELEVAN, S.G., SKALÍK, I., STEVENS, R.K. and LEWTAS, J., 1996. Teplice Program - The impact of air pollution on human health. Environmental Health Perspectives, vol. 104, suppl. 4, pp.699-714. http://dx.doi.org/10.1289/ehp.104-1469669. PMid:8879999.

SUD, V.S. and SUD, V.K.S., 2017. A review of toxic effects and aphrodisiac action of Morchella Esculenta (Wild MorelGuchhi Mushroom) - a Himalayan Delight. European Journal of Pharmaceutical and Medical Research, vol. 4, no. 8, pp. 726-730.
TREJO, N., MATUS, I., DEL POZO, A., WALTER, I. and HIRZEL, J., 2016. Cadmium phytoextraction capacity of white lupine (Lupinus albus L.) and narrow-leafed lupine (Lupinus angustifolius L.) in three contrasting agroclimatic conditions of Chile. Chilean Journal of Agricultural Research, vol. 76, no. 2, pp. 228-235. http:// dx.doi.org/10.4067/S0718-58392016000200013.

WADE, M.G., FOSTER, W.G., YOUNGLAI, E.V., MCMAHON, A., LEINGARTNER, K., YAGMINAS, A., BLAKEY, D., FOURNIER, M., DESAULNIERS, D. and HUGHES, C.L., 2002. Effects of subchronic exposure to a complex mixture of persistent contaminants in male rats: systemic, immune, and reproductive effects. Toxicological Sciences: An Official Journal of the Society of Toxicology, vol. 67, no. 1, pp. 131-143. http://dx.doi.org/10.1093/ toxsci/67.1.131.

WAISBERG, M., JOSEPH, P., HALE, B. and BEYERSMANN, D., 2003. Molecular and cellular mechanisms of cadmium carcinogenesis. Toxicology, vol. 192, no. 2-3, pp. 95-117. http://dx.doi.org/10.1016/ S0300-483X(03)00305-6. PMid:14580780.

WANG, H., ZHANG, R., SONG, Y., LI, T. and GE, M., 2019. Protective Effect of Ganoderma Triterpenoids on Cadmium-Induced Testicular Toxicity in Chickens. Biological Trace Element Research, vol. 187, no. 1, pp. 281-290. http://dx.doi.org/10.1007/s12011018-1364-4. PMid:29717433.

WANG, Z. and TEMPLETON, D.M., 1998. Induction of c-fos protooncogene in mesangial cells by cadmium. The Journal of Biological Chemistry, vol. 273, no. 1, pp. 73-79. http://dx.doi.org/10.1074/ jbc.273.1.73. PMid:9417049.

WASSER, S.P., 2002. Medicinal mushrooms as a source of antitumor and immunomodulating polysaccharides. Applied Microbiology and Biotechnology, vol. 60, no. 3, pp. 258-274. http://dx.doi. org/10.1007/s00253-002-1076-7. PMid:12436306.

WÄTJEN, W., BENTERS, J., HAASE, H., SCHWEDE, F., JASTORFF, B. and BEYERSMANN, D., 2001. Zn2+ and Cd2+ increase the cyclic GMP level in PC12 cells by inhibition of the cyclic nucleotide phosphodiesterase. Toxicology, vol. 157, no. 3, pp. 167-175. http:// dx.doi.org/10.1016/S0300-483X(00)00370-X. PMid:11164982.

WONG, E.W.P. and CHENG, C.Y., 2011. Impacts of environmental toxicants on male reproductive dysfunction. Trends in Pharmacological Sciences, vol. 32, no. 5, pp. 290-299. http:// dx.doi.org/10.1016/j.tips.2011.01.001. PMid:21324536.

WORLD HEALTH ORGANIZATION - WHO, 1960. Exposure to cadmium: a major public health concern. Geneva: WHO, pp. 3-6.

YANG, P.M., CHIU, S.J., LIN, K.A. and LIN, L.Y., 2004. Effect of cadmium on cell cycle progression in chinese hamster ovary cells. Chemico-Biological Interactions, vol. 149, no. 2-3, pp. 125136. https://doi.org/10.1016/j.cbi.2004.08.001.

YUN, W. and HALL, I.R., 2004. Edible ectomycorrhizal mushrooms: challenges and achievements. Canadian Journal of Botany, vol. 82, no. 8, pp. 1063-1073. http://dx.doi.org/10.1139/b04-051.

ZHANG, W., WU, T., ZHANG, C., LUO, L., XIE, M. and HUANG, H., 2017. Cadmium exposure in newborn rats ovary induces developmental disorders of primordial follicles and the differential expression of SCF/c-kit gene. Toxicology Letters, vol. 280, pp. 20-28. http://dx.doi.org/10.1016/j.toxlet.2017.08.004. PMid:28801138.

ZHUANG, P., MCBRIDE, M.B., XIA, H., LI, N. and LI, Z., 2009. Health risk from heavy metals via consumption of food crops in the vicinity of Dabaoshan mine. The Science of the Total Environment, vol. 407, no. 5, pp. 1551-1561. http://dx.doi.org/10.1016/j. scitotenv.2008.10.061. PMid:19068266. 